\title{
KEPEMIMPINAN KEPALA SEKOLAH PADA SMA KRISTEN KOTA KOTAMOBAGU
}

\author{
Swita Klaudia Pangulu1, Marsel Johan Tumbelaka ${ }^{2}$ \\ 1,2Institut Agama Kristen Negeri Manado \\ email: switapangulu94@gmail.com
}

\begin{abstract}
The purpose of this study was to determine how the leadership of the principal at Kotamobagu Christian Senior High School, the characteristics of serving leadership from the principal, the supporting factors for the implementation of the serving leadership of the principal, and the factors that constrain the principal as a serving leader. The method used in this research is a descriptive qualitative method which is carried out in Christian High School at Kota Kotamobagu. Data were collected through observation, interviews, and documentation study. From the results of the analysis and interpretation of the data, it is then obtained (1) The leadership of the principal is leadership with a firm and tough figure, always based on the rules that apply in school, and is very concerned about the entire process of activities in the school. (2) Paying attention to all school activities, always prioritizing the welfare of teachers, not taking care of being a leader. (3) There is control from the foundation to attend school, there is supervision from the education office, and there is support from all school elements for the leadership of the school principal. (4) the principal's inability to control emotions, there is no dispensation for students who have not paid tuition fees, said the principal who often does not show an example. From these findings, it follows: The principal must know and understand how leadership serves according to the biblical perspective.
\end{abstract}

Keywords: Leadership, Principal, Christian High School.

\section{PENDAHULUAN}

Pemimpin adalah seseorang yang diberikan kepercayaan ataupun mandat untuk menjadi ketua (kepala) dalam suatu sistem organisasi, lembaga, ataupun perusahaan. Seorang pemimpin, harus bisa mengetahui dan menguasai tugas kerja yang hendak dilakukan, karena semua keberhasilan dan kegagalan suatu organisasi, lembaga ataupun perusahaan tergantung pada kepemimpinan.

Menurut Usman Effendi fungsi kepemimpinan ialah mengacu pada satu tujuan yakni agar setiap rencana bahkan setiap harapan yang diinginkan dapat tercapai dengan berbagai macam fungsi harus dilaksanakan dan dijalankan. Agar kelompok dapat berjalan dengan baik dan efektif layaknya kelompok yang profesional, pemimpin harus melaksanakan beberapa fungsi diantaranya: (a) fungsi yang berhubungan dengan tanggungjawab dalam mengatasi setiap masalah serta dalam menanganinya; (b) fungsi 
untuk menerapkan kerjasama dan kebersamaan dalam kelompok maupun sosial, agar dapat memperoleh hasil yang maksimal, membuat rancangan dengan kelompok yang lain, menjadi penengah dalam setiap hal yang terjadi. Dengan demikian melalui fungsi kepemimpinan, seorang pemimpin dapat lebih jelih lagi dalam memainkan perannya sebagai penggerak utama dalam suatu organisasi atau perusahaan demi mencapai suatu tujuan. Berbicara tentang kepemimpinan, dunia pendidikan pula ada dalam lingkup kepemimpinan, karena tujuan dari pendidikan itu sendiri hendak tercapai ketika adanya kepemimpinan yang dapat mengatur, mengolah, bahkan berusaha untuk merancang semua aktifitas dalam pendidikan agar dapat terlaksana dengan baik, demi untuk mencapai tujuan dari pendidikan itu sendiri. Membahas tentang kepemimpinan dalam dunia pendidikan, di sekolah juga kepala sekolah adalah pemimpin pada institusi pendidikan, sebagaimana pemimpin harus melaksanakan fungsi kepemimpinannya maka demikian juga kepala sekolah diharapkan dapat melaksanakan fungsi kepemimpinannya baik melalui pelayanan, administratif, akademik, inovasi/pembaharuan, maupun pelayanan kerohanian warga sekolahnya. Kepala sekolah juga dalam melaksanakan tugasnya bukan hanya berorientasi pada produk pekerjaan tetapi juga harus berorientasi pada kesejahteraan kemanusiaan guru-guru, dan pegawai administrasinya.

SMA Kristen Kotamobagu, merupakan salah satu sekolah Kristen di Kota Kotamobagu dan dapat dikatakan, bahwa sekolah ini merupakan salah satu sekolah favorit di Kota Kotamobagu, yang juga merupakan destinasi favorit bagi para pelajar di Kotamobagu dan sekitarnya. Kenyataan bahwa sekolah ini merupakan sekolah favorit, maka dapat dikatakan juga bahwa sekolah ini merupakan barometer bagi pendidikan menengah Kristen di Kota Kotamobagu. Sebagai sebuah sekolah Kristen, maka fungsi kepemimpinan kepala sekolah bukan hanya dari segi leadership dan manajerial semata, namun memiliki tanggung jawab sebagai teladan hidup yang baik bagi orang-orang yang dipimpinnya, baik guru, pegawai, maupun para siswa yang bersekolah di sekolah itu. Sebagai sekolah Kristen, maka fungsi kepemimpinan juga mencakup di dalamnya fungsi pelayanan spiritual/kerohanian dari warga sekolahnya.

Perlu diperhatikan lebih dalam lagi bahwa Kepala Sekolah pada SMA Kristen Kotamobagu, belum sepenuhnya memahami bagaimana seharusnya kepemimpinan dari seorang pemimpin. Kepala sekolah belum terpantau sebagai sosok pemimpin yang melayani, serta belum tepat dalam menyeleksi dan menempatkan guru-guru dalam pembelajaran pada mata pelajaran yang sebenarnya bukan menjadi skil dan bidangnya, bahkan dalam pengawasan dan bimbingan masih kurang efektif, begitu pula dalam penilaian hasil kerja juga masih belum professional dalam memainkan perannya sebagai seorang pemimpin/kepala sekolah. Masih terdapat adanya kesenjangan antara kepemimpinan kepala sekolah sebagai pemimpin yang diharapkan melayani dengan kenyataan yang diperoleh di lapangan.

Dengan demikian maka, penulis termotivasi untuk melakukan penelitian ini dengan melibatkan wakil kepala sekolah, guru-guru, tata usaha, dan siswa sebagai satu 
elemen yang ada dalam lingkungan sekolah, demi untuk mengukur kinerja dan kepelayanan dari kepala sekolah ketika menjalankan peranannya sebagai sosok pemimpin sekolah, yang bercirikan kepelayanan.

\section{METODE PENELITIAN}

Pendekatan yang digunakan dalam penelitian ini yaitu pendekatan penelitian kualitatif. Metode yang digunakan adalah metode deskriptif analitik, dan rancangan penelitian mengikuti anjuran dari Miles dan Huberman berdasarkan penjelasan Moleong. Adapun tempat penelitian dilaksanakan di SMA Kristen Kotamobagu selama kurang lebih tujuh bulan dari bulan Januari sampai dengan bulan Juli 2020. Dalam pelaksanaan penelitian ini instrumen penelitian adalah peneliti sendiri. Selain itu peneliti juga menggunakan instrument penunjang, antara lain catatan lapangan, alat perekam audio, dan kamera foto. Hal ini berguna untuk memudahkan peneliti dalam mengumpulkan, menganalisa dan memahami informasi yang digali dari sumber di lapangan. Kemudian, Data dalam penelitian ini adalah informasi yang didapatkan peneliti dari sumber data yang menjadi informan penelitian ini melalui teknik observasi, wawancara dan dokumen yang berkaitan dengan rumusan masalah, dan sumber data dalam penelitian ini berupa orang (kepala sekolah, wakil kepala sekolah, guru-guru, tata usaha, komite sekolah, orang tua/wali, dan siswa), tempat (lokasi penelitian, dokumen, sebagai sumber dalam penelitian ini). Dalam penelitian ini, peneliti menggunakan prosedur penelitian sebagai tata cara kerja untuk melaksanakan berbagai tindakan bahkan hal-hal tertentu demi menuju pada capaian yang hendak diharapkan yaitu memperoleh data di lapangan melalui observasi dan juga wawancara serta studi dokumentasi.

\section{HASIL DAN PEMBAHASAN}

\section{Konsep Dasar Kepemimpinan}

Konsep dasar Kepemimpinan dapat ditinjau salah satunya dari pendapat J.R. Paus yang menyatakan bahwa kepemimpinan atau leadership merupakan suatu usaha menggunakan pengaruh untuk memotivasi individu dalam mencapai beberapa tujuan. Davis mendefinisikan dengan adanya kepemimpinan adalah kemampuan untuk mengajak orang lain dalam mencapai tujuan yang sudah ditentukan dan disepakati dengan penuh rasa semangat. Dapat dikatakan bahwa kepemimpinan merupakan sebuah seni mempengaruhi, dengan berorientasi pada pencapaian tujuan yang diharapkan. Seorang pimpinan dituntut agar dapat memberdayakan semua potensi yang dimilikinya, termasuk potensi yang ada pada setiap orang yang dipimpinnya, untuk bersama-sama mencapai satu tujuan. Selain itu, kepemimpinan juga merupakan perilaku dari seorang individu yang memimpin aktivitas-aktivitas suatu kelompok kesuatu tujuan yang ingin dicapai bersama (shared goal). Dari situ dapat kita katakan bahwa penetapan dan pemahaman akan tujuan memegang peranan yang penting bagi 
suatu kepemimpinan. Sebab tanpa kesepakatan bersama untuk mencapai tujuan, maka kepemimpinan yang dijalankan akan menjadi tidak efekti, karena masing-masing anggota tidak mengerti dan memahami tugas dan fungsi masing-masing dalam pencapaian tujuan. Sehingga dengan demikian maka dapat kita katakana bahwa kepemimpinan leadership merupakan salah satu pilar utama dalam kegiatan organisasi (O.U Effendi). A.W Tunggal, Kepemimpinan adalah proses mengarahkan dan mempengaruhi aktivitas-aktivitas yang berhubungan dengan tugas dari anggotaanggota kelompok. Dengan demikian maka seorang pemimpin harus berupaya untuk memberdayakan setiap orang yang ada dalam sebuah kelompok, agar mereka dapat mengeluarkan kemampuan terbaik yang dimiliki dengan tujuan produktivitas dan efektifitas kerja.

M.C Ulum, Dalam interaksi antara pemimpin (leader) dan pengikut (follower), pemimpin adalah figur pertama yang mengambil inisiatif perubahan dan mengkomunikasikannya kepada para pengikut untuk mendapatkan respons yang positif (baik dalam hal perilaku maupun kinerja). Eileen Rachman, Pemimpin yakni orang atau manusia yang telah dipercayakan dalam satu tanggungjawab yang hendak dilaksanakan, oleh karena itu manusia yang adalah pemimpin memerlukan juga kerjasama dari manusia yang lain dalam setiap misi kepemimpinannya. Berdasarkan uraian-uraian tentang kepemimpinan maka dapat disimpulkan bahwa kepemimpinan merupakan proses untuk bisa menjadi hal yang dapat berpengaruh pada orang lain dan menjadi pengarah untuk bawahan, kelompok, individual, bahkan lembaga dalam suatu proses sehubungan dengan aktivitas yang sedang dikerjakan sehingga setiap anggota suatu kelompok dapat diberdayakan secara optimal untuk meningkatkan produktivitas dan efektifitas kelompok tersebut untuk mancapai tujuan yang diharapkan.

\section{Model-model Kepemimpinan}

Husaini Usman mengemukakan beberaoa model kepemimpinan, yaitu: transformasional, kontongensi, partisipatif dan dan jalur tujuan. Berikut ini akan diuraikan masing-masing model kepemimpinan tersebut.

a. Transformasional: Model ini cenderung berbuat sewenang-wenang, karena kepemimpinan yang kuat, berani berkorban sebagai pahlawan, karismatik dan konsisten dengan teman sejawat dalam berbagai nilai-nilai dan kepentingankepentingan umum. Jika model ini berjalan optimal, maka model ini melibatkan stakeholders dalam mencapai tujuan.

b. Kontingensi: Model Kepemimpinan ini lebih fokus pada situasi dan mengevaluasi bagaimana menyesuaikan perilakunya dengan lingkungan. Model ini lebih cenderung pada situasi yang senantiasa menjadi pengendali serta pengaruh terhadap seorang pemipin, atau dengan kata lain kesesuaian pemimpin dengan kondisi dan tempat di mana ia sedang melaksanakan tugasnya dalam sebagai pemimpin. 
c. Partisipatif: Model kepemimpinan partisipatif berasumsi bahwa lebih cenderung pada keputusan bersama-sama, Artinya mengundang bawahannya untuk ikut terlibat dalam memberikan aspirasinya.

d. Jalur Tujuan: lebih terpusat pada antusias seorang pemimpin untuk mempengaruhi persepsi bawahannya dengan memberikan penghargaan atas apa yang telah dikerjakan oleh bawahannya. Serta pemimpin harus mampu untuk meneri dorongan serta semangat bagi bawahannya dalam bentuk apresiasi, agar bawahannya juga akan ikut serta terdorong untuk melalkukan apa yang hendak dikerjakan.

\section{Tipe-tipe Kepemimpinan}

Wahjosumidjo, yang dimaksud dengan tipe kepemimpinan tidak lain adalah pola perilaku yang ditampilkan oleh seorang pemimpin pada saat pemimpin itu mencoba untuk mempengaruhi orang lain sepanjang diamati oleh orang lain. Daniel C. Kambey, Ada beberapa tipe kepemimpinan yakni antara lain tipe kepemimpinan yang otokrasi, demokrasi, militeristik, karismatik, Laissez-Faire.

a. Otokrasi: Tipe ini menunjukkan bahwa yang berhak dalam pengambilan keputusan seutuhnya dan mengambil suatu kebijakan ialah seorang pemimpin, tidak harus bersandar pada bawahannya.

b. Demokratis: Pemimpin selalu bersedia menerima dan menghargai saran-saran, pendapat dan nasehat dari sataf dan bawahannya, melalui keputusan rapat. Seorang pemimpin yang demokratik menyadari bahwa institusinya harus dijalankan sedemikian rupa sehingga menggambarkan secara jelas berebagai tugas dan kegiatan yang harus dilaksanakan demi tercapainya tujuan organisasinya.

c. Militeristik: Tipe ini menunjukkan seorang pemipin yang lebih suka atau lebih sering untuk memerintah akan orang lain atau anak buahnya, serta lebih senang dengan kekuasaan yang dipegangnya, kemuudian tidak suka juuga untuk diberikan kritikan ataupun saran dari orang lain, lebih suuka dengan pendapatnya sendiri sebagai pimpinan.

d. Karismatik: Pemimpin dalam tipe ini mempunyai sifat yang lebih khas dalam mempengaruhi orang lain sehingga ia menjadi pusat perhatian dari orang lain dan sering juga orang lain selalu ikut dalam setiap perintah bahkan keinginan dari pemimpin ini. Dengan tipe ini sangatlah baik untuk seorang pemimpin dengan tujuan bersama tim karena hendak menggambarkan bahwa tim yang dipimpinnya begitu senang dan antusias dengan peran dari pimpinan mereka sehingga tim selalu akan ikut serta pada arahan dari pimpinan mereka.

e. Laissez-Faire: Pemimpin memberikan tugas serta tanggungjawab pebuh kepada bawahannya untuk pelaksanaan pekerjaan, serta setiap hal-hal yang berhubungan dengan semua setiap pekerjaan diputuskan oleh bawahan yang sudah ditugaskan. Jadi dapat dikatakan pemimpin menyerahkan sepenuhnya setiap tugas dan tanggungjawab kepada bawahannya dalam melaksanakan 
pekerjaan, sehingga tidak ada arahan bahkan pengawasan dari pimpinan itu sendiri. Tipe pemimpin atau kepemimpinan seperti ini kurang menenpati dan memainkan peranannya sebagai seorang pemimpin, karena seringkali yang menjadi tugas sebagai pemimpin hanya diserahkan kepada bawahannya untuk malaksanakannya.

\section{Kepemimpinan Kepala Sekolah}

Wahyosumidjo, Kepala sekolah merupakan pimpinan yang dipercayakan untuk mengelola satu lembaga yakni sekolah yang di dalamnya menjadi tempat untuk menerima ilmu dan pendidikan. Aan Komariah, kepala Sekolah adalah manager yang dimandatkan untuk mangatur segala yang ada dalam sekolah itu sendiri, serta kepala sekolah juga merupakan seorang pendidik yang menjadi dasar serta patokan untuk keberlangsungan proses dalam sekolah sehingga dapat mencapai tujuan dari pendidikan. Untuk itulah berhasil tidaknya sekolah itu tergantung juga pada pengelolaan dari pimpinan sekolah yakni kepala sekolah itu sendiri. Wahyosumidjo kepala sekolah merupakan satu jabatan yang pada dasarnya telah ditetapkan berdasarkan pada beberapa kriteria yang telah disepakati dan juga ada pada orang tersebut yang dipilih untuk menjadi manager dalam sekolah. Menjadi kepala sekolah juga harus melalui bergabagai prosedur bahkan fase-fase yang harus dilalui sesuai dengan peraturan yang berlaku. Kepala sekolah juga dapat dikatakan sebagai satu profesi yang pada hakikatnya untuk menguasai akan kedudukan tersebut dalam segala potensi bahkan bakat yang ada. Selain itu, Kepala sekolah merupakan salah satu komponen pendidikan yang paling berperan dalam meningkatkan kualitas pendidikan. Sebagaimana dikemukakan dalam peraturan pemerintah Nomor 28 tahun 1990 pasal 12 ayat 1 bahwa: kepala sekolah bertangung jawab atas penyelenggaraan kegiatan pendidikan, administrasi sekolah, pembinaan pegawai lainnya, dan pendayagunaan serta pemeliharaan sarana dan prasarana. Herawati, kepemimpinan kepala sekolah merupakan suatu kemampuan dan kesiapan kepala sekolah untuk mempengaruhi, membimbing, mengarahkan, dan menggerakkan staf sekolah agar dapat bekerja secara efektif dalam rangka mencapai tujuan pendidikan dan pengajaran yang telah ditetapkan atau bisa dikatakan bantuan yang diberikan oleh kepala sekolah terhadap penetapan pencapaian tujuan pendidikan. Mulsyasa kepala sekolah adalah manajer puncak suatu sekolah, ia bertanggungjawab atas manajemen yang terselenggara. Kepala sekolah bertanggungjawab atas langkah-langkah manajemen yang terjadi dan tingkat keberhasilannya.

Kepala Sekolah yang adalah sebagai seorang pemimpin secara ideal harus mengetahui dan melakukan berbagai macam keterampilan yakni menguasai cara menyusun rencana bersama, mengajak anggota berpartisipasi, memberi bantuan kepada anggota kelompok, memupuk semangat kerja kelomok, bersama-sama membuat keputusan, dan mengembangkan kerja sama di dalam kelompok, serta membagi dan menyerahkan tanggung jawab. Oleh karenanya, kepala sekolah yang merupakan satu jabatan tunggal tidak dapat digantikan tanpa melalui prosedur atau langkah-langkah 
yang ada berlandaskan pada ketentuan yang berlaku, serta dengan jabatan selaku kepala sekolah harus menjalankan tugas dengan sebaik-baiknya dan harus bisa untuk mencapai tujuan yang diharapkan. Kepala sekolah sebagai pendidik harus memberikan secara jelas dan mendalam akan setiap materi yang hendak diajarkan kepada siswa, serta harus mampu untuk merancang setiap pembelajaran pada keberhasilan. Kepala sekolah juga harus mampu untuk memenuhi setiap keperlan sekolah yakni sarana dan prasarana yang diperlukan sekolah demi untuk jalannya pelaksanaan pendidikan yang baik, efekttif dan efisien. Serta kepala sekolah juga harus mempu untuk memberikan berbagai layanan yang terbaik baik untuk guru maupun siswa dalam melaksanakan proses belajar mengajar, kemudian kepala sekolah perlu juga melaksanakan efaluasi dalam setiap semester demi untuk melihat segala perkembangan sekolah dan melakukan penyuluhan juga di lingkungan sekolah.

\section{Pemimpin Sebagai Pelayan}

Konsep kepemimpinan dalam Alkitab memperlihatkan dimensi yang berbeda dengan kepemimpinan umum yang telah dibahas di atas. Jika dalam banyak terminology pemimpin/kepemimpinan sebagai sosok atau figur yang memiliki kuasa dan wewenang untuk memerintah, namun Alkitab memperlihatkan sisi kepelayanan dalam kepemimpinan.

Teks Alkitab yang banyak digunakan sebagai rujukan bagi pola kepemimpinan servantt leader, adalah perkataan Tuhan Yesus yang terdapat dalam Markus 10:42-45.

Dalam teks tersebut ada beberapa kata kunci yang merujuk pada konsep servantt leader, yaitu: pelayan, hamba dan melayani.

Novum, Kata pelayan dalam teks ini, diterjemahkan dari bahasa Yunani diakonos yang berarti hamba, atau seseorang yang memberikan pelayanan dan bantuan kepada orang lain, dalam beberapa konteks dengan implikasi status yang lebih rendah; atau orang yang menjalankan perintah orang lain (tuan).

Kemudian ada beberapa hal penting sehubungan dengan kepemimpinan servant leader. (1) Dalam perspektif kekristenan pemimpin adalah orang yang mau dan menyediakan diri untuk melayani orang-orang yang dipimpinnya. (2) Kebesaran seorang pemimpin, bukan dilihat dari seberapa tinggi kedudukan yang dimiliki, melainkan dilihat dari seberapa besar ia bersedia untuk menjadi hamba dan pelayan bagi sesamanya. (3) Seorang pemimpin adalah orang yang membuka dirinya untuk melayani, memperhatikan dan memenuhi kebutuhan dari orang-orang yang dilayaninya (bnd. Pengertian melayani, sebagai pelayanan di meja makan). (4) Penggunaan kata "budak/hamba/doulos" memperlihatkan bahwa posisi kepemimpinan bukan terutama dilihat dari sisi posisi, melainkan dari sisi fungsional. (5) Ada dimensi kerendahan hati dalam kepemimpinan Kristen. Secara factual pemimpin mempunyai kuasa untuk memerintah dan dilayani. Namun kerendahan hati sebagai seorang hamba membuat pemimpin mengambil posisi sebagai hamba yang melayani sesamanya. John MacArthur 
menuliskan, bahwa pemimpin bukan orang yang berambisi pada kesuksesan dan kepentingan pribadi, melainkan seorang yang menunjukkan bahwa kepentingan orang yang dipimpinnya adalah prioritas dalam hidupnya. Hal ini membuat pemimpin sejati akan bekerja keras untuk membuat orang-orang disekitarnya berkembang atau mencapai keberhasilannya.

Konsep kepemimpinan dalam konsep servantt leader adalah: pelayan yang benarbenar mau memberikan diri dalam pengabdian, untuk melayani Tuhan dan umatNya, bersedia hidup bersama dengan orang yang dipimpinnya dan mengorientasikan hidup dan pelayanannya bagi orang-orang yang ia layani.

\section{Pembahasan Kepemimpinan Kepala Sekolah SMA Kristen Kota Kotamobagu}

Berdasarkan hasil observasi lapangan, peneliti kemudian mengemukakan bahwa Kepala Sekolah SMA Kristen Kotamobagu begitu antusias memperhatikan guru-guru dan siswa dalam pembelajaran dan dalam kegiatan-kegiatan di sekolah, penulis juga melihat bahwa kepala sekolah sendiri seringkali lupa dan mengabaikan tanggung jawabnya di sekolah sebagai pimpinan sekolah, karena ketika sudah menyepakati untuk mengadakan rapat akan tetapi kepala sekolah sendiri tidak hadir di sekolah dengan faktor lupa, begitu pula ketika sudah ada perjanjian dengan kepala sekolah seringkali kepala sekolah lupa dengan adanya perjanjian untuk bertemu di sekolah. Kepala sekolah juga terlihat lebih memperhatikan bawahannya serta semua kegiatan di sekolah namun dari kegiatannya sendiri sebagai kepala sekolah seringkali tidak diperhatikan. Dalam melayani tamu juga kepala sekolah masih belum terlalu santun ketika sedang berkomunikasi.

Selanjutnya, berdasarkan temuan-temuan yang telah dideskripsikan, maka berikut dilakukan pembahasan terhadap temuan penelitian tersebut.

\section{Fungsi Kontrol Kepala Sekolah dalam Operasional Sekolah}

Kepala Sekolah SMA Kristen Kotamobagu dalam mengontrol dan mengelola sistem pembelajaran di sekolah serta kegiatan-kegiatan yang ada di sekolah kepala sekolah memberikan yang terbaik dengan cara dan tindakannya yang begitu antusias, agar supaya setiap proses pembelajaran dapat berjalan semestinya serta guru-guru yang bertugas dapat melaksanakan tanggung jawabnya dan siswa-siswa juga dapat terkontrol untuk mengikuti kegiatan pembelajaran. Kepala sekolah terlihat memberi diri dalam setiap aktifitas yang terjadi di sekolah namun seringkali kepala sekolah sendiri terbengkalai dengan tugas dan aktifitasnya yang seringkali sudah tidak dapat dikerjakan. Kepala sekolah terlalu sibuk dengan mengatur orang lain akan tetapi seringkali tugas dan tanggung jawabnya sudah tidak dapat lagi terlaksana dengan baik dan sering tidak bercermin dari diri sendiri sebagai seorang pimpinan sekolah karena apa yang dikatakan oleh kepala sekolah kepada guru-guru dan siswa tidak dilakukan oleh kepala sekolah. 


\section{Kepala Sekolah sebagai Teladan Hidup}

Novianty Djafiri, fungsi kepemimpinan adalah sebagai berikut: memimpin dengan visi yang jelas, memimpin dengan keteladanan, seorang komunikator yang trampil, mampu memenangkan kepercayaan para pengikutnya, tenang menghadapi situasi yang sulit, mampu mengundang ketidak pahaman secara konstruktif, tampil dengan citra profesional, mampu membuat perkara yang rumit menjadi sederhana, mampu bekerja dan membuat keberhasilan bersama tim, senang membentu orang lain berhasil, seorang pelaku sukses yang sejati, seorang yang menghindari politik kantor dan tidak menerapkan favoritisme.

Fungsi kepemimpinan Kepala sekolah sebagai teladan, menyiratkan bahwa dalam kepemimpinannya memiliki sosok figur pemimpin yang tegas bahkan termasuk pemimpin yang keras dalam memimpin namun sikap kepala sekolah yang tegas dan keras adalah untuk kebaikan dan demi perkembangan sekolah agar menjadi lebih baik, akan tetapi kepala sekolah harus tahu untuk mengontrol emosi ketika hendak memberikan arahan yang baik kepada siswa maupun kepada guru karena ketika kepala sekolah memberikan arahan dalam bentuk tindakan yang keras dan tidak terkontrol lagi hanya akan membuat halhal yang tidak diinginkan terjadi seperti siswa sudah tidak suka lagi untuk ke sekolah, begitu juga guru-guru akan malas untuk ke sekolah, karena sikap dan tindakan kepala sekolah yang seringkali membuat kecewa orang lain melalui tutur kata yang kasar. Sikap dan tindakan kepala sekolah yang memiliki figur yang tegas dan keras merupakan pembawaan dari sikap dan tindakan pribadi (dari dalam). Kepala sekolah juga mempunyai sikap yang menjunjung tinggi setiap peraturan yang berlaku di sekolah, oleh karena itu kepala sekolah selalu memperhatikan akan ketepatan waktu ketika tiba di sekolah bahkan waktu ketika jam pulang sekolah, serta setiap peraturan yang berlaku di sekolah salalu menjadi landasan dari kepala sekolah dalam kepemimpinannya, kepala sekolah juga sangat memperhatikan setiap kegiatan di sekolah serta proses pembelajaran selalu di kontrol baik dari siswa maupun guru-guru. Kepala sekolah juga merupakan sosok kepala sekolah yang jujur dalam memimpin karena semua hal yang terjadi kepala sekolah selalu mempunyai sikap yang terbuka. Kepala sekolah juga begitu aktif dalam memimpin, Kepala sekolah pula memiliki sikap yang netral yang tidak memandang bulu ketika memimpin dan pada dasarnya kepala sekolah memimpin berlandaskan pada visi dan misi dari sekolah. Serta kepala sekolah juga dalam kepemimpinannya telah melakukan banyak perkembangan yakni melalui perekembangan pembangunan sekolah yang sudah mulai terealisasi. Akan tetapi kepala sekolah walaupun dalam kepemimpinan-nya dari segi mengembangkan sekolah sudah baik namun dalam figurnya yang tegas dan keras juga harus bisa diperhatikan kembali, karena figur yang tegas sekalipun katika sudah tidak dapat terkontrol lagi dapat terjadi hal-hal yang tidak diharapkan bahkan tidak akan menjadi panutan yang tidak baik dalam kepemimpinannya. 


\section{Kepemimpinan yang Melayani sebagai Model Kepemimpinan Kepala Sekolah}

Kepala sekolah sebagai pemimpin memang secara teori dapat dikatakan sebagai pemimpin yang melayani namun pada kenyataannya melalui wawancara, dan observasi di lapangan, tidak semua hal sebagai pemimpin yang melayani dilakukan oleh kepala sekolah, peneliti mendapatkan bahwa kepala sekolah dari segi pembangunan begitu kerja keras dalam meningkatkan akan kualitas sekolah dalam segi pembangun sekolah, begitu juga dengan sikap kepala sekolah yang merupakan sikap sebagai pemimpin yang tegas dengan setiap peraturan. Memang sebagai pemimpin harus bisa memiliki sikap yang tegas namun, tegas dalam artian tetap mengikuti aturan yang ada serta dapat mengontrol emosi. Tetapi yang peneliti dapatkan kepala sekolah dalam membawah dirinya sebagai seorang pemimpin yang melayani belum sepenuhnya melakukan apa yang sebenarnya dilakukan oleh seorang pemimpin pelayan yang sesungguhnya, akan tetapi kepala sekolah juga antusias dalam memperhatikan berbagai hal bahkan aktivitas yang terjadi di sekolah demi menciptakan suasana sekolah yang baik, taat akan aturan serta apa yang di harapkan dapat tercapai. Namun ada hal yang sangat mendasar sebagai seorang pemimpin pelayan yang seharusnya meneladani akan sosok dari pemimpin-pemimpin Alkitab yang hendak mengantar pada proses sebagai pemimpin pelayan yang sesungguhnya. Karena yang peneliti peroleh bahwa kepala sekolah masih saja melakukan hal yang tidak menunjukkan sikap sebagai pemimpin pelayan dalam hal tutur kata dan sifat yang terlalu keras, dimana kepala sekolah ketika memberikan arahan dan bimbingan bagi guruguru dan siswa sering tidak terkendali dalam mengeluarkan kata-kata yang seringkali menyinggung bahkan membuat guru dan siswa menjadi tertekan dan takut bahkan ada siswa yang sudah tidak mau lagi untuk kesekolah karena takut pada kepala sekolah.

Begitupun guru ketika menerima arahan dari kepala sekolah seringkali sudah tidak suka lagi datang di sekolah karena malu dengan kata-kata dari kepala sekolah bahkan ada pula guru yang bahkan harus dikeluarkan dari sekolah karena sudah tidak pernah masuk sekolah, akan tetapi ketika kepala sekolah memberikan arahan kepada guru tersebut walaupun melalui telepon, sangat tidak menghargai, bahkan mengeluarkan kata-kata yang sebenarnya tidak pantas untuk dikatakan. Dari sinilah dapat dilihat bagaimana kepala sekolah dalam memimpin yang melayani belum menunjukkan sikap sebagai pemimpin pelayan yang sesungguhnya berdasarkan pemimpin dalam Alkitab dengan teladan-teladan yang seharusnya dapat diikuti. Memang dapat dikatakan kepala sekolah melakukan hal-hal tersebut demi untuk meningkatkan kualitas sekolah agar menjadi lebih baik, namun di sisi lain sebagai pemimpin pelayan yang meneladani sosok pemimpin dalam Alkitab seharusnya bisa melakukan dengan berbagai cara agar supaya tidak juga membuat perasaan dan hati dari orang yang ditegur manjadi takut dan tidak lagi ingin untuk ke sekolah. Padahal yang seharusnya seorang kepala sekolah 
dalam memimpin apalagi dalam memimpin sekolah Kristen harus benar-benar berjiwa sebagai seorang pelayang yang sesungguhnya bukan hanya dari beberapa hal akan tetapi dari penguasaan diri harus juga bisa diterapkan oleh seorang pemimpin pelayan. Agar supaya dapat dikatakan sebagai pemimpin pelayan yang sesungguhnya melayani, dalam semua aspek kepemimpinan.

Dengan memahami pola kepemimpinan servant leader, maka begitu jelas bahwa pemimpin bukan orang yang mau mencari keuntungan dari orang yang dipimpinnya, melainkan mereka yang mau berkorban bagi orang yang dipimpin dan dilayani. Dia berusaha dengan segala cara untuk menghidupi mereka, bukan hidup dari mereka. Mungkin terdengar sangat klise dan konseptual. Pemimpin dalam konteks atau budaya masyarakat sering menjadi sangat direktif. Kebanyakan dari mereka menggunakan perintah. Namun kepemimpinan yang melayani dalam pengabdian dan pemberian diri tidaklah demikian. Ia tidak hanya memerintah tetapi melakukan. Dia tidak hanya memberikan perintah, namun memberikan contoh dan teladan.

Karakteristik pribadi yang memiliki figur yang keras adalah salah satu faktor yang menjadi kendala kepala sekolah sebagai pemimpin yang melayani karena dari sosok kepala sekolah seringkali mengeluarkan kata-kata yang kurang pantas untuk dikatakan kepada siswa ketika dalam memberikan arahan bagi siswa pada saat apel dan pada saat di dalam kelas, serta dari kepala sekolah tidak memberikan dispensasi kepada siswa dalam pembayaran SPP sehingga seringkali ada beberapa siswa yang memang tidak bisa mengikuti ujian di sekolah karena belum bisa melunasi akan setiap pembayaran di sekolah. Kepala sekolah juga seringkali tidak bisa mengendalikan emosi sehingga ada beberapa sikap yang keluar dari diri seorang kepala sekolah sebagai pemimpin tidak menunjukkan teladan yang baik sebagaimana seharusnya pemimpin yang melayani. Oleh sebab itu kepala sekolah ketika memberikan arahan bagi siswa dan sebagian guru bukan meberikan arahan yang membangun dan membuat motivasi bagi guru dan siswa akan tetapi hanya membuat siswa dan guru menjadi kendor dalam aktifitas mereka di sekolah.

Konsep kepemimpinan sebagai seorang pelayan merupakan konsep kepemimpinan dalam Alkitab. Kepemimpinan sebagai pelayan yang bersumber dari dalam Alkitab memperlihatkan dimensi yang berbeda dengan kepemimpinan umum. Jika dalam banyak terminology pemimpin/kepemimpinan sebagai sosok atau figur yang memiliki kuasa dan wewenang untuk memerintah, namun dalam Alkitab memperlihatkan sisi kepelayanan dalam kepemimpinan. Karena itu sebagai seorang pemimpin di sekolah, maka seorang kepala sekolah diharapkan memiliki karakter sebagai hamba. Sehingga fungsi kepemimpinan dapat berjalan dalam konsep kepelayanan yang melayani. 


\section{KESIMPULAN}

Kepala Sekolah SMA Kristen Kotamobagu dipandang baik dan tegas bagi semua elemen yang ada dalam sekolah, karena dengan adanya kepala sekolah sekarang, sekolah terlihat sudah semakin berkembang dalam segi pembangunan dan dalam proses pembelajaran serta dalam kegiatan sekolah selalu ikut ambil bagian, berbeda dengan kepala sekolah yang sebelumnya. Namun dari segi pemimpin yang melayani kepala sekolah belum sepenuhnya menunjukkan sikap sebagai pemimpin yang malyani yang sesungguhnya dari segi tutur kata, pembinaan dan tidak adanya dispensasi kepada siswa dalam hal membayar uang sekolah, sehingga tidak dapat mengikuti ujian. Namun, Kepala sekolah tidak meneladani sosok kepemimpinan dalam Alkitab sebagai pemimpin yang melayani. Kepala sekolah memimpin hanya berlandaskan dengan aturan yang menjadi patokan utama dalam proses kepemimpinan. Kepemimpinan kepala sekolah terlalu disegani oleh sebagian guru-guru, staf sekolah, dan siswa.

\section{REFERENSI}

Djafiri, Novianty. Manajemen Kepemimpinan Kepala Sekolah. Yogyakarta: Deepublish, 2016.

Effendi, Onong Uchjana. Ilmu Komunikasi Teori dan Praktek (Bandung: Remaja Rosdakarya, 2004.

Effendi, Usman. Asas Manajemen, Jakarta: PT. Raja Grafindo, 2011.

Herawati, Penerapan Kepemimpinan Kepala Sekolah Dalam Meningkatkan Kinerja Guru Pada Jenjang Sekolah Menengah Pertama (SMP), Jurnal IDAARAH, Vol.1, Makasar: UMI, 2017.

Kambey, Daniel C. Landasan Teori Administrasi/Manajemen. Manado: Yayasan Tri Ganesha Nusantara, 2010.

Komariah, Aan. Visionary Leadership Menuju Sekolah Efektif. Jakarta: PT. Bumi Aksara, 2005

MacArthur, John. Kitab Kepemimpinan, Jakarta: BPK Gunung Mulia, 2009.

Moleong, Lexy. Metode Penelitian Kualitatif. Bandung Remaja Karya, 2007.

Mulsyasa, Manajemen Berbasis Sekolah, Konsep, Strategi dan Implementasi, Bandung: Remaja Rosdakarya, 2005.

Novum Testamentum Gerika. Jakarta: LAI, 1997.

Paus, Juldus Rulaand. Kepemimpinan \& Kinerja Pamong Belajar (Malang: CV. Seribu Bintang, 2019.

Rachman, Eileen. Sukses Jadi Pemimpin, Jakarta: Gramedia Pustaka Utama, 2017. 
Tim Penyusun, Kamus Besar Bahasa Indonesia. Jakarta: Pusat Bahasa Departemen Pendidikan Nasional, 2008.

Tunggal, Amin Widjaja. Manajemen. Jakarta: PT. Rineka Cipta,2014.

Ulum, M. Chazienul. Leadership. Dinamika Teori Pendekatan dan Isu Strategis Kepemimpinan di Sektor Publik, Malang: UB Press, 2012.

Usman, Husaini. Manajemen Teori, praktik, dan Riset Pendidikan. Jakarta: Bumi Aksara, 2011.

Wahjosumidjo, Kiat Kepemimpinan Dalam Teori Dan Praktek. Jakarta: PT. Harapan Masa PGRI, 1994.

Wahyosumidjo. Kepemimpinan Kepala Sekolah. Jakarta PT. Raja Grafindo Persada 2007. 